\title{
Effectiveness of Various Mosquito Attractant Solutions to Control Mosquito Population
}

\author{
Lia Faridah, ${ }^{1}$ Christian Albert, ${ }^{2}$ Nisa Fauziah ${ }^{1}$ \\ ${ }^{1}$ Division of Parasitology, Department of Biomedical Science, ${ }^{2}$ Medical Undergraduate Study Program, \\ Faculty of Medicine, Universitas Padjadjaran, Bandung, Indonesia
}

\begin{abstract}
The vector-borne disease is a disease caused by an organism that can transmit disease between human or animal to human. In Indonesia, several vector-borne diseases are a burden of the government including dengue fever, chikungunya, filariasis, and malaria. The attractive baited lethal ovitrap (ALOT) is a novel strategy to alleviate mosquito populations in three main actions: attraction, an adulticide, and larvacide. Research using plant infusion can attract mosquitoes to lay their eggs is needed. This study aims to compare the effectiveness of the mosquito repellent solution using materials from organic waste in Bandung. This study was a quantitative analytic study with a quasi-experimental design conducted in the Faculty of Medicine Universitas Padjadjaran area in October 2016-July 2017. Research subjects are mosquito eggs in a solution which placed at 25 different places for every solution. The analysis was performed using Kruskal-Wallis test followed by the Dunn test. The result of the KruskalWallis test indicates the difference of effectiveness of each solution $(\mathrm{p}<0.05)$. Based on the results of the Dunn test, the most significant difference found in the solution of wood shavings with the vegetable waste solution and the solution of wood shavings with corn straw $(\mathrm{p}<0.05)$. In conclusion, there is a difference in the effectiveness of the mosquito repellent solutions and the most attractive solution for mosquitoes to oviposit is the corn straw solution.
\end{abstract}

Key words: Effectiveness, mosquito population, mosquito attractant solution

\section{Efektivitas Berbagai Larutan Penarik Nyamuk untuk Mengontrol Populasi Nyamuk}

\begin{abstract}
Abstrak
Penyakit tular vektor adalah penyakit yang disebabkan oleh organisme yang dapat mentransmisikan penyakit antarmanusia atau hewan ke manusia. Di Indonesia, terdapat beberapa penyakit tular vektor yang masih menjadi beban pemerintah, di antaranya demam berdarah, chikungunya, penyakit kaki gajah, dan malaria. Attractive baited lethal ovitrap (ALOT) merupakan strategi baru untuk menurunkan populasi nyamuk dalam tiga aksi utama, yaitu attraction, adulticide, dan larvacide. Penelitian terkait larutan dari tanaman yang dapat menarik nyamuk sangat diperlukan. Penelitian ini bertujuan membandingkan efektivitas larutan penarik nyamuk dengan menggunakan bahan dari limbah organik yang ada di Kota Bandung. Penelitian ini adalah penelitian analitik kuantitatif dengan desain quasi-eksperimental yang dilakukan di lingkungan Fakultas Kedokteran Universitas Padjadjaran pada bulan Oktober 2016-Juli 2017. Subjek penelitian merupakan telur nyamuk yang ada pada larutan yang diletakkan pada 25 titik untuk setiap larutan. Analisis dengan Uji Kruskal-Wallis yang dilanjutkan dengan Uji Dunn. Hasil penelitian dengan Uji Kruskal-Wallis menunjukkan perbedaan efektivitas tiap-tiap larutan ( $\mathrm{p}<0,05)$. Berdasar atas hasil Uji Dunn, perbedaan yang paling signifikan terdapat pada larutan serutan kayu dengan larutan sampah sayur dan larutan serutan kayu dengan jerami jagung $(\mathrm{p}<0,05)$. Simpulan, terdapat perbedaan efektivitas larutan penarik nyamuk dan larutan yang menarik nyamuk paling banyak untuk bertelur adalah larutan jerami jagung.
\end{abstract}

Kata kunci: Efektivitas, larutan penarik nyamuk, populasi nyamuk 


\section{Introduction}

The vector-borne disease is a disease caused by a microorganism on the human population. Vector is a living organism that can transmit disease from human or animal to human. ${ }^{1}$ Mosquito is one of the prominent vectors besides fly, flea, and some aquatic snails. ${ }^{2}$ In Indonesia, there are four major diseases transmitted by a mosquito, that is dengue, chikungunya, filariasis, and malaria. ${ }^{3,4}$

Several attempts on vector control have been made such as diminishing resources (eliminate any the container capable of the storing water), larviciding (temephos, Bacillus thuringiensis), biologic control (mosquito-eating fish), and the adulticiding (room spray, insecticide-treated nets, lethal ovitrap as well as autocidal ovitrap). The attractive baited lethal ovitrap (ALOT) is a novel strategy that is designed to alleviate mosquito populations in three main actions: 1) attraction; 2) adulticide; 3) larvacide. Study regarding the effectiveness of organic solution based attractant studied various times, some of which are using the hay infusion, ${ }^{5}$ grass infusion, ${ }^{6}$ chicken manure infusion, ${ }^{7}$ guava leaves and potato skin infusion, ${ }^{8}$ and oak leaves infusion. ${ }^{9}$ The research using plant infusion can enhance egg excretion by mosquitoes..$^{10}$ However, a study regarding the most effective attractant using organic waste from Bandung city and Sumedang regency have not done. Therefore, this study was conducted to determine the most effective solution to attract the mosquitoes as one of the autocidal ovitrap components that will distribute to the community as an attempt to control the mosquito population to decrease the incidence of mosquito-borne disease.

\section{Methods}

This study is a quantitative analytic study with a quasi-experimental design conducted in the Faculty of Medicine Universitas Padjadjaran area in October 2016-July 2017. Research subjects are mosquito eggs in a solution which placed at 25 different places for every solution. Ovitrap placed on region conserved from the rainwater. This study has got permission from the Faculty of Medicine Universitas Padjadjaran and ethical approval from the Health Research Ethics Committee of Faculty of Medicine Universitas Padjadjaran with letter number: $382 /$ UN6.C.10/ $\mathrm{PN} / 2017$.

Making a solution begins with drying the ingredients until parched. Components utilized are the corn straw, rice straw, wood shavings, vegetable waste (Chinese cabbage), fruit waste (guava, melon skin, watermelon skin, and jicama skin), weed, and water hyacinth. Those materials used because easily found as organic waste in the community. Parched ingredients were put inside a bucket containing tap water with a ratio of 500 grams in 120-liter water, closed tightly, then left for seven days. After seven days, the solution filtered. ${ }^{11}$

The study begins with putting the filtered solution into a 1.5-liter black container which patched with filter paper surfacing the inside area of the container. Each container comprising different solution placed in 13 regions outside room and 12 areas inside the room due to limited active rooms used as depicted in Figure, then ovitrap was left for seven days. After that, the whole eggs found calculated. The data analyzed with the Kruskal-Wallis test and proceed with the Dunn test.

\section{Results}

Data obtained from the calculation of the number of eggs contained in each solution is in Table 1. Based on the data, the least amount of eggs found in ovitrap placed in the parasitology laboratory room. The most number of eggs found in ovitrap placed in the hallway of buildings $\mathrm{C}_{1}$ and $\mathrm{C}_{4}$.

Results of data analysis using the KruskalWallis test showed a significant difference in the number of eggs found in each solution $(\mathrm{p}<0.05)$. The tested solution can be sorted based on its effectiveness in attracting the mosquitoes to lay eggs. In Table 2, it can see that the most effective solution for attracting mosquitoes is a solution made from corn straw.

Results of the Kruskal-Wallis test showed a significant difference, and then the data analyzed with the Dunn test to compare the two solutions and see whether the differences between the two solutions were significantly or not. Dunn test results were in Table 3. The Dunn test results showed that there were significant differences ( $p<0.05$ ), namely the solution of wood shavings compared to vegetable waste, and corn straw.

\section{Discussion}

Results of egg calculation in this study indicate a difference in the number of eggs found in each solution. Several factors influence this difference 


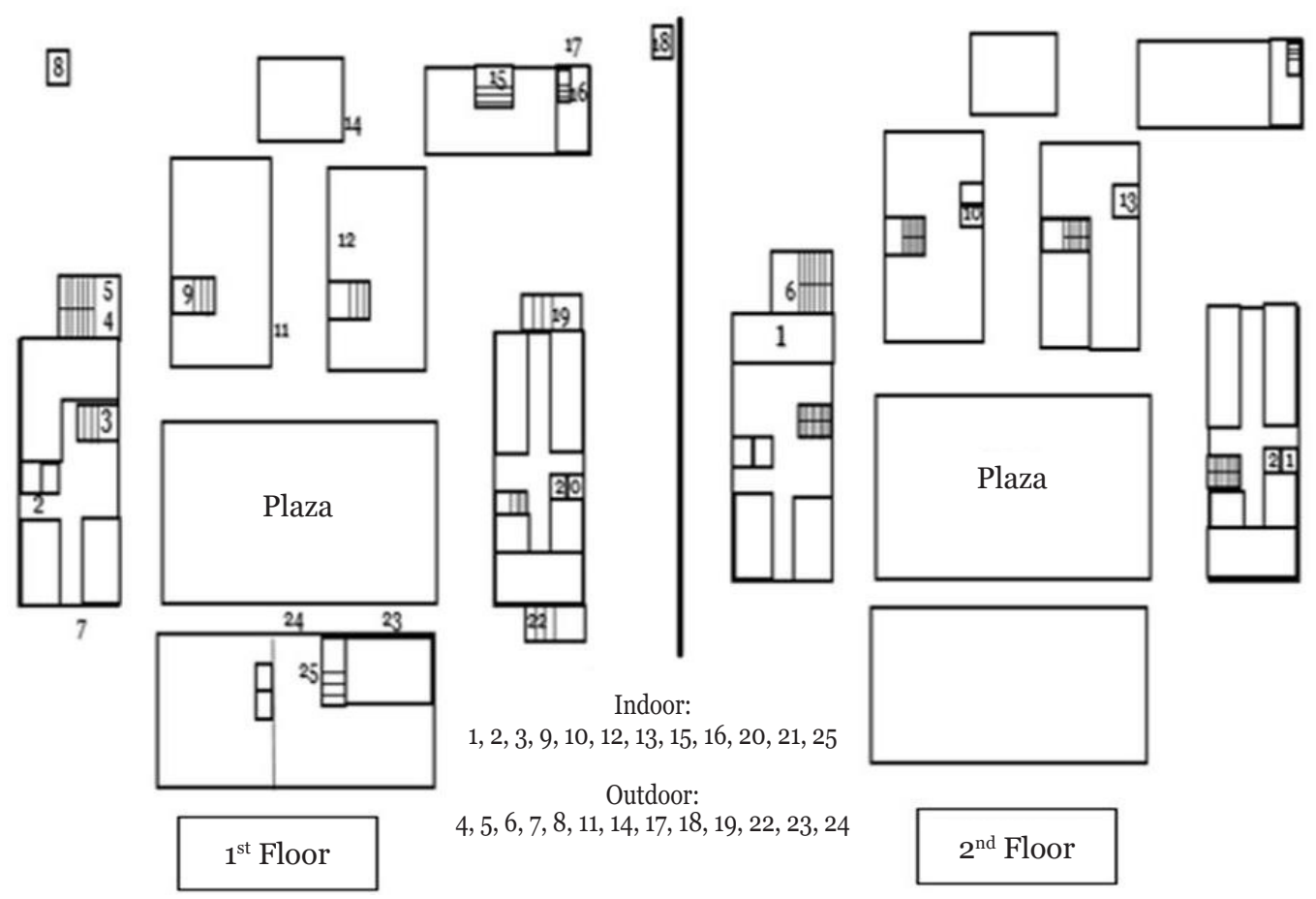

Figure Ovitrap Placement Layout

Table 1 Density of Eggs on Each Solution

\begin{tabular}{|c|c|c|c|c|c|c|c|c|}
\hline \multirow{2}{*}{ No. } & \multirow{2}{*}{ Place } & \multicolumn{7}{|c|}{ Solution Types } \\
\hline & & Fruit & Vegetable & Wood & Grass & Corn & Rice & Water Hyacinth \\
\hline 1 & Parasites Lab. & 0 & o & 1 & 2 & 1 & 4 & 0 \\
\hline 2 & Front of toilet $\mathrm{C}_{4}$ & 1 & 3 & 1 & 5 & 2 & 2 & 3 \\
\hline 3 & Under stairs in building $\mathrm{C}_{4}$ & 1 & 1 & o & 5 & 5 & 5 & o \\
\hline 4 & Under stairs outside building $\mathrm{C}_{4}$ & 4 & 5 & 4 & 5 & 5 & 3 & 5 \\
\hline 5 & $1^{\text {st }}$-floor stairs outside building $\mathrm{C}_{4}$ & 2 & 2 & o & 1 & 3 & 4 & 1 \\
\hline 6 & $2^{\text {nd }}$-floor stairs outside building $\mathrm{C}_{4}$ & 1 & 4 & 1 & 4 & 4 & 4 & 1 \\
\hline 7 & Hallway C4.1 & 5 & 5 & 5 & 5 & 5 & 5 & 5 \\
\hline 8 & Security post $\mathrm{C}_{5}$ & 5 & 5 & 2 & 5 & 5 & 4 & 2 \\
\hline 9 & Under stairs in building $\mathrm{C}_{5.1}$ & 3 & 5 & 1 & 0 & 5 & 2 & o \\
\hline 10 & Men's toilet in $\mathrm{C}_{5} .2$ & $\mathrm{o}$ & 3 & o & 0 & 1 & o & $\mathrm{O}$ \\
\hline 11 & Hallway $\mathrm{C}_{5} .1$ & 4 & 3 & 4 & 5 & 3 & 5 & 2 \\
\hline 12 & 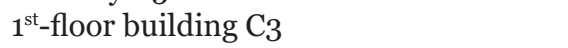 & 5 & 3 & 5 & 3 & 5 & 5 & 3 \\
\hline 13 & Men's toilet in library & 3 & 5 & o & 2 & 4 & 1 & 1 \\
\hline 14 & Household building of FK Unpad* & 5 & 5 & 2 & 5 & 5 & 5 & 5 \\
\hline 15 & Under stairs of musala & 5 & 5 & 2 & 5 & 5 & 4 & 5 \\
\hline 16 & Stairs C6 & 1 & 5 & 5 & 2 & 5 & 3 & 2 \\
\hline 17 & Hallway C6.1 & 5 & 5 & 1 & 4 & 5 & 3 & 5 \\
\hline 18 & Security post C6 & 5 & 5 & 4 & 5 & 5 & 5 & 5 \\
\hline 19 & Stairs C2 & O & 5 & 1 & 5 & 5 & 5 & 5 \\
\hline 20 & Men's toilet in $1^{\text {st }}$-floor of building $\mathrm{C}_{2}$ & 3 & 5 & 5 & $\mathrm{O}$ & 5 & 5 & 2 \\
\hline 21 & Men's toilet in $2^{\text {nd }}$-floor of building $\mathrm{C}_{2}$ & 2 & o & 2 & 3 & 3 & 1 & 1 \\
\hline 22 & Hallway $\mathrm{C}_{2}$ & 5 & 5 & 2 & 2 & 5 & 5 & 5 \\
\hline 23 & Hallway in front of entrance building $\mathrm{C} 1$ & 5 & 5 & 5 & 5 & 5 & 5 & 4 \\
\hline 24 & Hallway $\mathrm{C}_{1}$ & 5 & 5 & 5 & 5 & 5 & 5 & 5 \\
\hline \multirow[t]{2}{*}{25} & In front of men's toilet in building $\mathrm{C} 1$ & 5 & 5 & 2 & 5 & 5 & 5 & 5 \\
\hline & Median & 4 & 5 & 2 & 5 & 5 & 4 & 3 \\
\hline
\end{tabular}

${ }^{*}$ FK Unpad: Faculty of Medicine Universitas Padjadjaran; ${ }^{* *}$ musala: prayer room; 0: 1-10, 1: 11-20, 2: 21-30, 3: 31-40, 4: 41-50, 5: >50; numbers in the table can be adjusted accordingly Figure 
Table 2 Ranking of Attractants Solution

\begin{tabular}{lrr}
\hline Type of Solutions & n & Mean Rank \\
\hline Fruit trash & 25 & 82.32 \\
Vegetable garbage & 25 & 102.70 \\
Wood shavings & 25 & 61.26 \\
Grass & 25 & 90.82 \\
Corn straw & 25 & 109.06 \\
Rice straw & 25 & 94.62 \\
Water hyacinth & 25 & 75.22 \\
Total & 175 & \\
p value & & 0.006 \\
\hline
\end{tabular}

because female mosquitoes will choose and determine where habitat is possible for larvae to grow, develop and survive visual, tactile, and olfactory stimuli. ${ }^{12}$ Besides, female mosquitoes determine their spawning grounds physically in terms of the lighting, color, temperature, and humidity and the chemical aspect of an attractant. ${ }^{13}$

Number of eggs on ovitrap placed in the parasitology laboratory is at least then the point of putting another ovitrap because humans rarely pass the room. Whereas the most trapped eggs found in the hallways of buildings $\mathrm{C} 1$ and $\mathrm{C} 4$, where there are many human activities. Female mosquitoes need food in the form of blood for the growth of their eggs. The blood required by mosquitoes comes from humans or animals. ${ }^{14,15}$

Results of data analysis using the KruskalWallis test showed differences in the number of eggs from each solution. The difference in the number of eggs had found in the attractant solution influenced by the composition of the amount and variation of the microorganism population..$^{16}$ The use of different solutions will affect the diverse composition of the microorganisms present in the solution. Mosquitoes are attracted to non-volatile chemistry on the surface of the solution detected by the chemotactile mosquito sensory organs. This non-volatile chemical is produced due to the fermentation process of microorganisms and will stimulate mosquitoes to lay eggs. ${ }^{17}$ Also, the quality and quantity of substances produced by attractants such as carbon dioxide and ammonia are different so that it will cause a difference in the attractiveness of each solution. ${ }^{18}$

According to the data obtained in Table 1 can be seen the mean value of each solution. The smallest middle value is in the solution of wood shavings, while the largest is the solution
Table 3 Comparison of Solutions

\begin{tabular}{ccl}
\hline Comparison & p Value & \multicolumn{1}{c}{ Result } \\
\hline B-S & 1.000 & Not significant \\
B-K & 1.000 & Not significant \\
S-K & 0.046 & Significant \\
B-R & 1.000 & Not significant \\
S-R & 1.000 & Not significant \\
K-R & 0.606 & Not significant \\
B-J & 0.395 & Not significant \\
S-J & 1.000 & Not significant \\
K-J & 0.008 & Significant \\
R-J & 1.000 & Not significant \\
B-P & 1.000 & Not significant \\
S-P & 1.000 & Not significant \\
K-P & 0.282 & Not significant \\
R-P & 1.000 & Not significant \\
J-P & 1.000 & Not significant \\
B-E & 1.000 & Not significant \\
S-E & 0.881 & Not significant \\
K-E & 1.000 & Not significant \\
R-E & 1.000 & Not significant \\
J-E & 0.255 & Not significant \\
P-E & 1.000 & Not significant \\
\hline
\end{tabular}

B: fruit trash, S: vegetable garbage, K: wood shavings, R: grass, J: corn straw, P: rice straw, E: water hyacinth

of vegetable waste, grass, and corn straw. In the Dunn test, the comparison of the solution of wood shavings with grass did not show a significant difference due to the uneven distribution of eggs in the grass solution.

Results of data analysis using the Dunn test showed a significant difference when comparing the solution of wood shavings with corn straw and wood shavings with vegetables. This difference occurs because the distribution of mosquito eggs in containers is uneven. The distribution of eggs in containers influenced by several factors, larvae, and pupae in solution, sun exposure, container size, and container cover. Larvae and nymphs in the solution can produce compounds as attractants that can attract female mosquitoes to lay eggs so those female mosquitoes will lay eggs in containers containing larvae and pupae. Container characteristics, sun exposure, and size have a secondary role. ${ }^{19}$ The influences of those things minimized using uniform containers and the same placement criteria for ovitrap both indoors and outdoors.

Overall, the Dunn test shows that there is a significant difference in the solution found in this study. The results of this study are not following the research conducted by Sazali et al. ${ }^{20}$ In the 
study they conducted showed no significant differences in the solution derived from organic materials, namely straw, chili, and palm sugar fermentation.

This study shows that the solution used in this study used as an ovitrap attractant, but several factors influence mosquitoes to put their eggs apart from substances produced from attractants.

Limitation in this study lies in the implementation of research. Researchers are aware of the constraints in this study that ovitrap is not fully awake from other animals such as cats so that the solution can be reduced or spilled.

Further research it is expected to be able to examine the microorganism content that can affect the attractant solution as a practical solution and needs to control external factors that can affect the effectiveness of attractants.

\section{Conclusions}

Organic ingredients can have used as an attractant for mosquitoes. There is a difference in the effectiveness of each solution as a mosquito pulling solution. The most effective solution is a solution made from corn straw.

\section{Conflict of Interest}

The authors declare no conflict of interest in this study.

\section{References}

1. World Health Organization (WHO). Vectorborne diseases [Internet]. WHO. 2017 [cited 2017 July 8]. Available from: https://www. who.int/news-room/fact-sheets/detail/ vector-borne-diseases.

2. Bhatia V, Rath RS, Singh AK. Developing the underdeveloped: aspirational districts program from public health point of view. Indian J Community Fam Med. 2018;4(2):24.

3. Ministry of Health Republic of Indonesia. Indonesia health profile 2014. Jakarta: Ministry of Health Republic of Indonesia; 2015.

4. Fakultas Kesehatan Masyarakat (FKM), Universitas Diponegoro. Kebijakan nasional pengendalian vektor terpadu [Internet]. FKM Undip. 2017 [cited 2018 April 13]. Available from: https://fkm.undip. ac.id $/$ new-site $/$ acara. html? view $=$ DOK UM201712011120440005.

5. Allan SA, Kline DL. Evaluation of organic infusions and synthetic compounds mediating oviposition in Aedes albopictus and Aedes aegypti (Diptera: Culicidae). J Chem Ecol. 1995;21(11):1847-60.

6. Santos SRA, Melo-Santos MAV, Regis L, Albuquerque CMR. Field evaluation of ovitraps consociated with grass infusion and Bacillus thuringiensis var. israelensis to determine oviposition rates of Aedes aegypti. Dengue Bull. 2003;27:156-62.

7. Kramer WL, Mulla MS. Oviposition attractants and repellents of mosquitoes: oviposition responses of Culex mosquitoes to organic infusions. Environ Entomol. 1979;8(6):1111-7.

8. Santos E, Correia J, Muniz L, Meiado M, Albuquerque C. Oviposition activity of Aedes aegypti L. (Diptera: Culicidae) in response to different organic infusions. Neotrop Entomol. 2010;39(2):299-302.

9. Trexler JD, Apperson CS, Schal C. Laboratory and field evaluations of oviposition responses of Aedes albopictus and Aedes triseriatus (Diptera: Culicidae) to oak leaf infusions. J Med Entomol. 1998;35(6):967-76.

10. Bellile KG, Vonesh JR. Bioinsecticide and leaf litter combination increases oviposition and reduces adult recruitment to create an effective ovitrap for Culex mosquitoes. J Vector Ecol. 2016;41(1):123-7.

11. Reiter P, Nathan MB. Guidelines for assessing the efficacy of insecticidal space sprays for control of the dengue vector Aedes aegypti [Internet]. WHO. 2001 [cited 2018 September 9]. Available from: https://apps.who.int/ iris/bitstream/handle/10665/67047/WHO CDS_CPE_PVC_2001.1.pdf.

12. Quiroz-Martínez H, Garza-Rodríguez MI, Trujillo-González MI, Zepeda-Cavazos IG, Siller-Aguillon I, Martínez-Perales JF, et al. Selection of oviposition sites by female Aedes aegypti exposed to two larvicides. J Am Mosq Control Assoc. 2012;28(1):47-9.

13. van Loon JJA, Smallegange RC, Bukovinszkiné-Kiss G, Jacobs F, De Rijk M, Mukabana WR, et al. Mosquito attraction: crucial role of carbon dioxide in formulation of a five-component blend of human-derived volatiles. J Chem Ecol. 2015;41(6):567-73.

14. Service M. Medical entomology for students. 
$5^{\text {th }}$ Edition. New York: Cambridge University Press; 2012.

15. Gunathilaka N, Ranathunge T, Udayanga L, Abeyewickreme W. Efficacy of blood sources and artificial blood feeding methods in rearing of Aedes aegypti (Diptera: Culicidae) for sterile insect technique and incompatible insect technique approaches in Sri Lanka. Biomed Res Int. 2017;2017:3196924.

16. Arbaoui AA, Chua TH. Bacteria as a source of oviposition attractant for Aedes aegypti mosquitoes. Trop Biomed. 2014;31(1):13442.

17. Salim M, Satoto TBT. Uji efektifitas atraktan pada lethal ovitrap terhadap jumlah dan daya tetas telur nyamuk Aedes aegypti. BPK.
2015;43(3):147-54.

18. Wahidah A, Martini, Hestiningsih R. Efektivitas jenis atraktan yang digunakan dalam ovitrap sebagai alternatif pengendalian vektor DBD di Kelurahan Bulusan. JKM. 2014;4(1):106-15.

19. Wong J, Stoddard ST, Astete H, Morrison AC, Scott TW. Oviposition site selection by the dengue vector Aedes aegypti and its implications for dengue control. PLoS Negl Trop Dis. 2011;5(4):e1015.

20. Sazali M, Samino S, Leksono AS. Attractiveness test of attractants toward dengue virus vector (Aedes aegypti) into lethal mosquiTrap modifications (LMM). IJMR. 2014;1(4):47-9. 